Jurnal Keperawatan Silampari

Volume 1, Nomor 2, Juni 2018

e-ISSN : 2581-1975

p-ISSN : 2597-7482

DOI: https://doi.org/10.31539/jks.v1i2.8

\title{
FAKTOR-FAKTOR YANG MEMPENGARUHI KUALITAS HIDUP PASIEN CHRONIC KIDNEY DISEASE (CKD) YANG MENJALANI HEMODIALISA
}

\author{
Handi Rustandi ${ }^{1}$, Hengky Tranado ${ }^{2}$, Tinalia Pransasti ${ }^{3}$ \\ Program Studi Ilmu Keperawatan, STIKES Dehasen Bengkulu ${ }^{1,2,3}$ \\ handi_rustandi@ymail.com ${ }^{1}$
}

\begin{abstract}
ABSTRAK
Tujuan penelitian untuk mengetahui faktor-faktor yang mempengaruhi kualitas hidup pasien CKD yang menjalani hemodialisa di RSUD Dr. M. Yunus Bengkulu tahun 2016. Jenis penelitian ini adalah penelitian deskriptif. Hasil penelitian menunjukkan hampir seluruh responden memiliki umur $<20$ dan $>35$ tahun, lebih dari sebagian responden memiliki jenis kelamin perempuan, lebih dari sebagian responden memiliki penghasilan cukup/lebih, sebagian dari responden memiliki tingkat depresi berat, lebih dari sebagian responden memiliki baik dalam dukungan keluarga, lebih dari sebagian responden memiliki kualitas hidup tinggi. Simpulan, ada hubungan antara usia, jenis kelamin, penghasilan, depresi,dan dukungan keluarga dengan kualitas hidup pasien CKD yang menjalani hemodialisa. Ada hubungan antara dukungan keluarga dengan kualitas hidup pasien CKD yang menjalani hemodialisa.
\end{abstract}

Kata Kunci: Chronic Kidney Disease (CKD), Hemodialisa, Kualitas Hidup

\section{ABSTRACT}

The purpose of this study was to determine the factors that influence the quality of life of CKD patients undergoing hemodialysis at RSUD dr. M. Yunus Bengkulu in 2016. This type of research is descriptive research. The results showed almost all respondents had age <20 and> 35 years, more than some respondents were female, more than some respondents had sufficient income / more, almost some of the respondents had severe depression levels, more than some respondents had both in family support, more than most respondents have a high quality of life. Conclusion, there is a relationship between age, sex, income, depression, and family support with the quality of life of CKD patients undergoing hemodialysis. There is a relationship between family support and the quality of life of CKD patients undergoing hemodialysis.

Keywords: Chronic Kidney Disease (CKD), Hemodialysis, Quality of Life 


\section{PENDAHULUAN}

Ginjal berfungsi untuk mengatur keseimbangan air dalam tubuh, mengatur konsentrasi garam dalam darah, dan keseimbangan asam-basa darah, serta eksresi bahan buangan dan kelebihan garam Apabila ginjal gagal menjalankan fungsinya, maka penderita memerlukan pengobatan dengan segera. Keadaan dimana ginjal lambat laun mulai tidak dapat melakukan fungsinya dengan baik disebut juga dengan Chronic Kidney Disease (CKD). CKD makin banyak menarik perhatian dan makin banyak dipelajari karena walaupun sudah mencapai tahap gagal ginjal terminal akan tetapi penderita masih dapat hidup panjang dengan kualitas hidup yang cukup baik (Kazama et al, 2009).

$C K D$ merupakan penyakit sistemik dan merupakan jalur akhir yang umum dari berbagai penyakit traktus urinarius dan ginjal (Suharyanto, Madjid, 2012). CKD adalah kemunduran fungsi dari ginjal ireversibel yang terjadi beberapa bulan atau tahun. Keadaan ini mengakibatkan ketidakmampuan dalam mempertahankan keseimbangan substansi tubuh atau akumulasi cairan dan produk sisa dengan menggunakan penanganan konservatif. Menurut Kidney Disease Outcome Quality Initiative merekomendasikan pembagian CKD berdasarkan stadium dari tingkat penurunan LFG (Laju Filtrasi Glomerolus): Stadium 1: kelainan ginjal yang ditandai dengan albuminaria persisten dan LFG yang masih normal ( $>90 \mathrm{ml} /$ menit / 1,73 $\mathrm{m}^{2}$ ) Stadium 2: Kelainan ginjal dengan albuminaria persisten dan LFG antara $60-89 \mathrm{~mL} / \mathrm{menit} / 1,73$ $\mathrm{m}^{2}$ ), Stadium 3: kelainan ginjal dengan LFG antara 30-59 mL/menit/1,73 $\mathrm{m}^{2}$ ), Stadium 4: kelainan ginjal dengan LFG antara $15-29 \mathrm{~mL} /$ menit/1,73 $\mathrm{m}^{2}$ ) Stadium 5: kelainan ginjal dengan LFG $<15 \mathrm{~mL} / \mathrm{menit} / 1,73 \mathrm{~m}^{2}$ atau gagal ginjal terminal (Pebriyana, 2015).

Pasien CKD yang mengalami gagal ginjal kronik akan menjalani hemodialisa jangka panjang, hemodialisa (HD) adalah suatu prosedur dimana darah dikeluarkan dari tubuh penderita dan beredar dalam sebuah mesin di luar tubuh yang disebut dialiser. Frekuensi tindakan HD bervariasi tergantung banyaknya fungsi ginjal yang tersisa, ratarata penderita menjalani tiga kali dalam seminggu, sedangkan lama pelaksanaan hemodialisa paling sedikit tiga sampai empat jam tiap sekali tindakan terapi (Brunner, Suddath, 2002). Masalah lain yang harus dihadapi pasien adalah seperti masalah finansial, kesulitan dalam mempertahankan pekerjaan, dorongan seksual yang hilang, depresi dan ketakutan terhadap kematian. Gaya hidup yang terencana berhubungan dengan terapi hemodialisa (misalnya pelaksanaan terapi hemodialisa 2-3 kali seminggu selama 3-4 jam) dan pembatasan asupan cairan sering menghilangkan semangat hidup pasien. Hal ini akan mempengaruhi kualitas hidup pasien CKD (Brunner, Suddarth, 2011).

Kualitas hidup merupakan keadaan dimana seseorang mendapat kepuasaan dan kenikmatan dalam kehidupan sehari-hari. Kualitas hidup tersebut menyangkut kesehatan fisik dan kesehatan mental yang berarti jika seseorang sehat secara fisik dan mental maka orang tersebut akan mencapai suatu kepuasan dalam hidupnya. Kesehatan fisik itu dapat dinilai dari fungsi fisik, keterbatasan peran fisik, nyeri pada tubuh dan persepsi tentang kesehatan. Kesehatan mental itu sendiri dapat dinilai dari fungsi sosial, dan keterbatasan peran emosional (Hays, 2010).

Wenger dalam (Yuwono, 2010) kualitas hidup merupakan integrasi dari publikasi keterbatasan, keluhan dan ciri-ciri psikologis yang menunjukkan kemampuan seseorang untuk melakukan bermacam-macam peran dan merasakan kepuasan dalam melakukan sesuatu. WHO telah merumuskan empat dimensi kualitas hidup yaitu dimensi fisik, dimensi psikologis, dimensi sosial dan dimensi lingkungan. Keempat dimensi tersebut 
sudah dapat menggambarkan kualitas kehidupan pasien CKD dengan terapi hemodialisa yang mempunyai latar belakang agama, etnis dan budaya yang berbeda (Aguswina, 2012).

Pasien GGK sebelum menjalani dialisis akan sangat terganggu aktivitasnya baik untuk bekerja maupun bergaul, juga kesulitan dalam tidur karena rasa sakit yang dirasakan. Disamping itu berbagai keluhan fisik dikeluhkan pasien tergantung dari tingkat keparahan penyakitnya dan komplikasi yang menyertai yang tidak sama antara satu pasien dengan pasien lainnya. Hal ini sesuai dengan teori yang mengatakan bahwa pasien GGK akan merasakan adanya rasa tidak nyaman, sesak, oedema, nyeri dada, rasa mual atau bahkan muntah, serta kram otot yang mengakibatkan nyeri hebat (Brunner, Suddath, 2002). Untuk itu pasien sangat tergantung pada terapi dialisis untuk meningkatkan kualitas hidupnya.

Proses hemodialisa membutuhkan waktu selama 4-5 jam umumnya akan menimbulkan stres, pasien akan merasakan kelelahan, sakit kepala, dan keluar keringat dingin akibat tekanan darah yang menurun Terapi HD juga akan mempengaruhi keadaan psikologis pasien. Pasien akan mengalami gangguan proses berpikir dan konsentrasi serta gangguan dalam berhubungan sosial. Semua kondisi tersebut akan menyebabkan menurunnya kualitas hidup pasien GGK yang menjalani terapi HD. Kualitas hidup pasien GGK yang menjalani terapi HD sangat dipengaruhi oleh beberapa masalah yang terjadi sebagai dampak dari terapi HD dan juga dipengaruhi oleh gaya hidup pasien (Suhud, 2005).

Desita (2010) dalam (Aguswina, 2012) menyakatan bahwa faktor-faktor yang mempengaruhi kualitas hidup dibagi menjadi dua bagian. Bagian pertama adalah sosial demografi yaitu jenis kelamin, umur, suku atau etnik, pendidikan, pekerjaan, dan status perkawinan. Kedua adalah tindakan medis yaitu lama manjalani hemodialisa, stadium penyakit, dan penatalaksanaan medis yang dijalani.

Dukungan keluarga dapat mempengaruhi kepuasan seseorang dalam menjalani kehidupan sehari-hari termasuk kepuasan terhadap status kesehatannya. Menurut Marilyn (2012) terdapat hubungan yang kuat antara keluarga dan status kesehatan anggotanya dimana peran keluarga sangat penting bagi setiap aspek perawatan kesehatan anggota keluarga, mulai dari strategi-strategi hingga fase rehabilitasi. Mengkaji dan memberikan perawatan kesehatan merupakan hal yang penting dalam membantu setiap anggota keluarga untuk mencapai suatu keadaan sehat hingga tingkat optimum.

Berdasarkan hasil survei data di RSUD Dr. M. Yunus Bengkulu didapat jumlah gagal ginjal pada tahun 2013 sebanyak 156 orang, sedangkan tahun 2014 terdapat 260 kasus berdasarkan survei awal pada tanggal 10 Nopember 2015 terhadap 8 orang yang menjalani tindakan hemodialisis, 3 orang mendapat dukungan dari keluarga, 3 orang tidak mendapat dukungan dan 2 orang kadang-kadang keluarga mendukung, kadangkadang keluarga tidak mendukung 8 pasien CKD tersebut juga menunjukkan adanya penurunan kualitas hidup akibat kurangnya dukungan keluarga. Rata-rata usia pasien yang menjalani hemodialisis di RSUD dr. M. Yunus Bengkulu > 40 tahun. 


\section{METODE PENELITIAN}

Jenis penelitian ini adalah penelitian deskriptif, dimana pengertian dari deskriptif adalah metode penelitian yang berusaha menggambarkan dan menghubungkan objek sesuai dengan apa adanya (Notoatmodjo, 2012). Dalam penelitian ini menggunakan pendekatan cross sectional adalah suatu penelitian untuk mempelajari dinamika korelasi antara faktor-faktor resiko dengan efek, dengan pendekatan, observasi atau pengumpulan data sekaligus pada suatu saat yang bersamaan untuk mengetahui hubungan dukungan sosial keluarga terhadap kualitas hidup pasien CKD yang menjalani hemodialisa di RSUD Dr. M. Yunus Bengkulu adapun teknik pengumpulan data yang digunakan dalam Penelitian ini adalah dengan menggunakan data Primer yaitu dengan menggunakan teknik accidental sampling dengan jumlah sampel 67 orang responden dan data sekunder. Data primer adalah data dikumpulkan dengan cara membagikan kuesioner kepada responden yang menjalani hemodialisa, data sekunder adalah data rekapitualisasi pasien CKD yang menjalani hemodialisa di RSUD Dr. M. Yunus Bengkulu 2016.

\section{HASIL PENELITIAN}

Filosofi Rumah Sakit Umum Bengkulu adalah diresmikan menjadi Rumah Sakit Umum Daerah Bengkulu dengan klasifikasi rumah sakit kelas B. Data yang di peroleh dari peneliti kemudian dikelompokkan ke dalam masing-masing variabel dan dilakukan pengkodean. Setelah itu data yang diperoleh dengan menggunakan sistem komputerisasi, selanjutnya dianalisis secara univariat dan bivariat.

Tabel. 1

Distribusi Frekuensi Gambaran Usia Pasien CKD yang Menjalani Hemodialisa

\begin{tabular}{ccc}
\hline Usia & Frekuensi & Persentase $(\%)$ \\
\hline$<20$ dan $>35$ tahun & 57 & 85,1 \\
20-35 tahun & 10 & 14,9 \\
\hline Jumlah & 67 & 100 \\
\hline
\end{tabular}

Berdasarkan Tabel 1 di atas dapat diketahui, hampir seluruh (85,1 ) memiliki usia $<20->35$ tahun.

Tabel. 2

Distribusi Frekuensi Gambaran Jenis Kelamin Pasien CKD yang Menjalani Hemodialisa

\begin{tabular}{ccc}
\hline Jenis kelamin & Frekuensi & Persentase $(\%)$ \\
\hline Laki-laki & 26 & 38,8 \\
Perempuan & 41 & 61,2 \\
\hline Jumlah & 67 & 100
\end{tabular}

Berdasarkan Tabel 2 dapat diketahui lebih dari sebagian $(61,2 \%)$ berjenis kelamin Perempuan. 
Tabel. 3

Distribusi Frekuensi Gambaran Penghasilan Pasien CKD yang Menjalani Hemodialisa

\begin{tabular}{ccc}
\hline Penghasilan & Frekuensi & Persentase $(\%)$ \\
\hline Kurang & 27 & 40,3 \\
Cukup/ Lebih & 40 & 59,7 \\
\hline Jumlah & 67 & 100 \\
\hline
\end{tabular}

Berdasarkan Tabel 3 di atas dapat diketahui, lebih dari sebagian $(59,7 \%)$ berpenghasilan cukup/lebih.

Tabel. 4

Distribusi Frekuensi Gambaran Depresi Pasien CKD yang Menjalani Hemodialisa

\begin{tabular}{ccc}
\hline Depresi & Frekuensi & Persentase (\%) \\
\hline Berat & 21 & 31,3 \\
Sedang & 6 & 9,0 \\
Ringan & 17 & 25,4 \\
Normal & 23 & 34,3 \\
\hline Jumlah & 67 & 100 \\
\hline
\end{tabular}

Berdasarkan Tabel 4 di atas dapat diketahui, hampir sebagian responden $(34,3 \%)$ memiliki kategori normal.

Tabel. 5

Distribusi Frekuensi Gambaran Dukungan Keluarga Pasien CKD yang Menjalani Hemodialisa

\begin{tabular}{ccc}
\hline Dukungan Keluarga & Frekuensi & Persentase (\%) \\
\hline Kurang & 24 & 35,8 \\
Baik & 43 & 64,2 \\
\hline Jumlah & 67 & 100 \\
\hline
\end{tabular}

Berdasarkan Tabel 5 di atas dapat diketahui, lebih dari sebagian $(64,2 \%)$ memiliki dukungan keluarga yang baik.

Tabel. 6

Distribusi Frekuensi Gambaran Kualitas Hidup Pasien CKD yang Menjalani Hemodialisa

\begin{tabular}{ccc}
\hline Kualitas hidup & Frekuensi & Persentase $(\%)$ \\
\hline Rendah & 11 & 16,4 \\
Sedang & 22 & 32,8 \\
Tinggi & 34 & 50,7 \\
\hline Jumlah & 67 & 100 \\
\hline
\end{tabular}

Berdasarkan tabel 6 di atas dapat diketahui, lebih dari sebagian $(50,7 \%)$ memiliki kualitas hidup tinggi. 
Tabel. 7

Analisis Hubungan Usia dengan Kualitas Hidup Pasien CKD yang Menjalani Hemodialis

\begin{tabular}{|c|c|c|c|c|c|c|c|c|c|}
\hline \multirow{3}{*}{ Umur } & \multicolumn{6}{|c|}{ Kualitas Hidup } & \multirow{2}{*}{\multicolumn{2}{|c|}{ Total }} & \multirow{3}{*}{$p$} \\
\hline & \multicolumn{2}{|c|}{ Rendah } & \multicolumn{2}{|c|}{ Sedang } & \multicolumn{2}{|c|}{ Tinggi } & & & \\
\hline & $\mathrm{N}$ & $\%$ & $\mathrm{~N}$ & $\%$ & $\mathrm{n}$ & $\%$ & $\mathrm{~N}$ & $\%$ & \\
\hline$<20$ dan $>35$ tahun & 6 & 10,5 & 20 & 35,1 & 31 & 54,4 & 57 & 100 & \\
\hline 20-35 tahun & 5 & 50 & 2 & 20 & 3 & 30 & 10 & 100 & 0,008 \\
\hline Jumlah & 11 & 16,4 & 22 & 32,8 & 34 & 50,7 & 67 & 100 & \\
\hline
\end{tabular}

Berdasarkan tabel 7 di atas dari 57 responden dengan umur $<20$ dan $>35$ tahun ada $31(54,4 \%)$ memiliki kualitas hidup tinggi. Sedangkan dari 10 responden umur 2035 tahun ada $5(50 \%)$ memiliki kualitas rendah. Hasil uji statistik (person chi-square) di dapat dengan nilai $p=0,008<0,05$, ada hubungan antara usia dengan kualitas hidup pasien CKD yang menjalani hemodialisa.

Tabel. 8

Analisis Hubungan Jenis Kelamin dengan Kualitas Hidup Pasien CKD yang Menjalani Hemodialisa

\begin{tabular}{|c|c|c|c|c|c|c|c|c|c|}
\hline \multirow{3}{*}{ Jenis Kelamin } & \multicolumn{6}{|c|}{ Kualitas Hidup } & \multirow{2}{*}{\multicolumn{2}{|c|}{ Total }} & \multirow{3}{*}{$\mathrm{P}$} \\
\hline & \multicolumn{2}{|c|}{ Rendah } & \multicolumn{2}{|c|}{ Sedang } & \multicolumn{2}{|c|}{ Tinggi } & & & \\
\hline & $\mathrm{N}$ & $\%$ & $\mathrm{~N}$ & $\%$ & $\mathrm{n}$ & $\%$ & $\mathrm{~N}$ & $\%$ & \\
\hline Laki-laki & 7 & 26,9 & 14 & 53,8 & 5 & 19,2 & 26 & 100 & \multirow{3}{*}{0,000} \\
\hline Perempuan & 4 & 9,8 & 8 & 19,5 & 29 & 70,7 & 41 & 100 & \\
\hline Jumlah & 11 & 16,4 & 22 & 32,8 & 34 & 50,7 & 67 & 100 & \\
\hline
\end{tabular}

Berdasarkan tabel 8 di atas dari 26 responden dengan jenis kelamin Laki-laki $7(26,9 \%)$ kualitas hidup rendah, Sedangkan dari 41 responden berjenis kelamin Perempuan 29 (70,7\%) memiliki kualitas tinggi. Hasil analisis (person chi-square) nilai $p=0,000<0,05$, ada hubungan antara jenis kelamin dengan kualitas hidup pasien CKD yang menjalani hemodialisa.

Tabel. 9

Analisis Hubungan Penghasilan dengan Kualitas Hidup Pasien CKD yang Menjalani Hemodialisa

\begin{tabular}{|c|c|c|c|c|c|c|c|c|c|}
\hline \multirow{3}{*}{ Penghasilan } & \multicolumn{6}{|c|}{ Kualitas Hidup } & \multirow{2}{*}{\multicolumn{2}{|c|}{ Total }} & \multirow{3}{*}{$P$} \\
\hline & \multicolumn{2}{|c|}{ Rendah } & \multicolumn{2}{|c|}{ Sedang } & \multicolumn{2}{|c|}{ Tinggi } & & & \\
\hline & $\mathrm{n}$ & $\%$ & $\mathrm{~N}$ & $\%$ & $\mathrm{n}$ & $\%$ & $\mathrm{~N}$ & $\%$ & \\
\hline Kurang & 8 & 29,6 & 15 & 55,6 & 4 & 14,8 & 27 & 100 & \\
\hline Cukup/Lebih & 3 & 7,5 & 7 & 17,5 & 30 & 75 & 40 & 100 & 0,000 \\
\hline Jumlah & 11 & 16,4 & 22 & 32,8 & 34 & 50,7 & 67 & 100 & \\
\hline
\end{tabular}

Berdasarkan Tabel tabel 9 di atas dari 27 responden dengan berpenghasilan Kurang terdapat ada $8(29,6 \%)$ reponden memiliki tingkat kualitas hidup rendah,. Sedangkan dari 40 responden berpenghasilan cukup/lebih, sebanyak $75 \%$ memiliki kualitas tinggi. Hasil uji statistic (person chi-square) nilai $p=0,000<0,05$, ada hubungan antara penghasilan dengan kualitas hidup pasien CKD yang menjalani hemodialisa. 
Tabel. 10

Analisis Hubungan Depresi dengan Kualitas Hidup Pasien CKD yang Menjalani Hemodialisa

\begin{tabular}{|c|c|c|c|c|c|c|c|c|c|}
\hline \multirow{3}{*}{ Depresi } & \multicolumn{6}{|c|}{ Kualitas Hidup } & \multirow{2}{*}{\multicolumn{2}{|c|}{ Total }} & \multirow{3}{*}{$P$} \\
\hline & \multicolumn{2}{|c|}{ Rendah } & \multicolumn{2}{|c|}{ Sedang } & \multicolumn{2}{|c|}{ Tinggi } & & & \\
\hline & $\mathrm{N}$ & $\%$ & $\mathrm{~N}$ & $\%$ & $\mathrm{n}$ & $\%$ & $\mathrm{~N}$ & $\%$ & \\
\hline Berat & 8 & 38,1 & 13 & 61,9 & 0 & 0 & 21 & 100 & \\
\hline Sedang & 2 & 33,3 & 1 & 16,7 & 3 & 50 & 6 & 100 & \\
\hline Ringan & 1 & 5,9 & 8 & 47,1 & 8 & 47 & 17 & 100 & 0,000 \\
\hline Normal & 0 & 0 & 0 & 0 & 23 & 100 & 23 & 100 & \\
\hline Jumlah & 11 & 16,4 & 22 & 32,8 & 34 & 50,7 & 67 & 100 & \\
\hline
\end{tabular}

Berdasarkan tabel 10 di atas, dari 21 responden dengan memiliki tingkat depresi berat terdapat $38,1 \%$ reponden memiliki tingkat kualitas hidup rendah, 6 responden memiliki tingkat Depresi sedang, sebanyak 16,7\% kualitas hidup sedang. Dari 17 responden memiliki tingkat Depresi ringan terdapat 5,9\% memiliki tingkat kualitas hidup rendah,. Sedangkan dari 23 responden memiliki tingkat depresi normal 100\% memiliki kualitas tinggi. Hasil uji statistik (person chi-square) dengan nilai $p=0,000<$ 0,05, ada hubungan antara depresi dengan kualitas hidup pasien CKD yang menjalani hemodialisa.

Tabel. 11

Analisis Hubungan Dukungan Keluarga dengan Kualitas Hidup Pasien CKD yang Menjalani Hemodialisa

\begin{tabular}{|c|c|c|c|c|c|c|c|c|c|}
\hline \multirow{3}{*}{$\begin{array}{l}\text { Dukungan } \\
\text { Keluarga }\end{array}$} & \multicolumn{6}{|c|}{ Kualitas Hidup } & \multirow{2}{*}{\multicolumn{2}{|c|}{ Total }} & \multirow{3}{*}{$p$} \\
\hline & \multicolumn{2}{|c|}{ Rendah } & \multicolumn{2}{|c|}{ Sedang } & \multicolumn{2}{|c|}{ Tinggi } & & & \\
\hline & $\mathrm{n}$ & $\%$ & $\mathrm{~N}$ & $\%$ & $\mathrm{n}$ & $\%$ & $\mathrm{~N}$ & $\%$ & \\
\hline Kurang & 11 & 45,8 & 9 & 37,5 & 4 & 16,7 & 24 & 100 & \\
\hline Baik & 0 & 0 & 13 & 30,2 & 30 & 69,8 & 43 & 100 & 0,000 \\
\hline Jumlah & 11 & 16,4 & 22 & 32,8 & 34 & 50,7 & 67 & 100 & \\
\hline
\end{tabular}

Berdasarkan Tabel 11 di atas, dari 24 responden dukungan keluarga terdapat 45,8\% reponden memiliki tingkat kualitas hidup rendah. Sedangkan dari 43 responden baik dalam dukungan keluarga terdapat sebanyak 69,8\% memiliki kulaitas tinggi. Dari hasil uji statistik person chi-square dengan nilai $p=0,000<0,05$, ada hubungan yang bermakna antara dukungan keluarga dengan kualitas hidup pasien CKD yang menjalani hemodialisa. 


\section{PEMBAHASAN}

\section{Analisis Univariat}

Berdasarkan usia, hasil penelitian menggambarkan distribusi usia pasien CKD yang menjalani hemodialisa di RSUD Dr. M. Yunus Bengkulu tahun 2016, dari 67 responden, sebanyak $(85,1 \%)$ memiliki usia $<20->35$ tahun. Hasil peneltian Zurmeli (2012) analisis data dari variabel umur menunjukkan mayoritas responden berada pada kategori dewasa tengah, yaitu sebanyak 72 orang $(68,6 \%)$. Berdasarkan hasil penelitian bahwa hampir seluruh pasien yang menjalani hemodialisa memiliki umur $<20$ dan $>35$ tahun sehingga terdapat hubungan yang positif antara usia terhadap kualitas hidup pasien CKD yang menjalani terapi hemodialisa di RSUD Dr. M.Yunus Bengkulu 2016.

Berdasarkan jenis kelamin, hasil penelitian menggambarkan distribusi jenis kelamin pasien CKD yang menjalani hemodialisa di RSUD Dr. M. Yunus Bengkulu tahun 2016, menunjukkan lebih dari sebagaian responden $(61,2 \%)$ memiliki jenis kelamin Perempuan. Berdasarkan hasil penelitian bahwa lebih dari sebagian pasien yang menjalani hemodialisa memiliki jenis kelamin perempuan sehingga terdapat hubungan yang positif antara jenis kelamin dengan kualitas hidup pasien CKD yang menjalani Hemodialisa di RSUD Dr.M.Yunus Bengkulu tahun 2016.

Berdasarkan penghasilan, hasil penelitian menggambarkan distribusi penghasilan pasien CKD yang menjalani hemodialisa di RSUD Dr. M. Yunus Bengkulu tahun 2016, menunjukkan lebih dari sebagian responden $(59,7 \%)$ memiliki penghasilan cukup/lebih.

Individu yang status sosial ekonominya berkecukupan akan mampu menyediakan segala fasilitas yang diperlukan untuk memenuhi kebutuhan hidupnya. Sebaliknya, individu yang status sosial ekonominya rendah akan mengalami kesulitan dalam memenuhi kebutuhan hidupnya (Sunaryo, 2004). Penghasilan yang rendah akan berhubungan dengan pemanfaatan pelayanan kesehatan maupun pencegahan. Seseorang kurang memanfaatkan pelayanan kesehatan yang ada mungkin karena tidak mempunyai cukup uang untuk membeli obat atau membayar tranportasi ke rumah sakit (Notoatmodjo, 2012).

Hasil penelitian Aguswina (2012) didapat nilai $\mathrm{p}=0,019$ yang artinya bahwa ada hubungan yang signifikan antara penghasilan/status ekonomi pasien dengan kualitas hidupnya. Dari hasil uraian diatas peneliti berasumsi bahwa faktor yang menyebabkan penghasilan atau status ekonomi pasien memiliki hubungan dengan kualitas hidup adalah responden yang diteliti dalam penelitian ini lebih dari sebagian berpenghasilan cukup/lebih.

\section{Depresi Pasien}

Diketahui hasil penelitian menggambarkan distribusi Depresi pasien CKD yang menjalani hemodialisa di RSUD Dr. M. Yunus Bengkulu tahun 2016, menunjukkan hampir sebagaian responden $(31,3 \%)$ memiliki tingkat depresi berat.

Brunner \& Suddarth (2011) dampak dari penyakit akut maupun kronis dapat menimbulkan beberapa reaksi emosional, salah satu dari reaksi emosional tersebut yaitu depresi. Berdasarkan data depresi didapatkan hampir sebagian responden memiliki perasaan depresi saat menjalani hemodialisa sehingga terdapat hubungan antara depresi dengan kualitas hidup pasien CKD yang menjalani hemodialisa di RSUD dr.M.Yunus Bengkulu 2016.

\section{Dukungan Keluarga}


Hasil penelitian menggambarkan distribusi dukungan keluarga pasien CKD yang menjalani hemodialisa di RSUD Dr. M. Yunus Bengkulu tahun 2016, menunjukkan lebih dari sebagaian responden $(64,2 \%)$ memiliki baik dalam dukungan keluarga.

Dari hasil analisis Zurmeli (2012) didapatkan bahwa lebih dari separuh dukungan yang diberikan oleh keluarga kepada responden yang mengalami gagal ginjal dan menjalani terapi hemodialisis adalah positif yaitu sebanyak 53 orang $(50,5 \%)$.

Artinya dapat diasumsikan bahwa keluarga telah melaksanakan fungsi tugas kesehatan keluarga. Berdasarkan pengamatan peneliti, rata-rata keluarga mendampingi pasien menjalani terapi hemodialisis hingga selesai dan memberikan dukungan emosional seperti memberikan perhatian dan semangat kepada pasien. Akan tetapi ada juga beberapa keluarga pasien yang kurang memberikan dukungan kepada pasien, seperti keluarga hanya mengantarkan pasien dan tidak menemani pasien menunggu antrian dan saat menjalani terapi hemodialisis.

\section{Kualitas Hidup}

Hasil penelitian menggambarkan distribusi kualitas hidup pasien CKD yang menjalani hemodialisa di RSUD Dr. M. Yunus Bengkulu tahun 2016, menunjukkan lebih dari sebagaian responden $(50,7 \%)$ memiliki kualitas hidup tinggi.

Menurut Suhud (2009) kualitas hidup adalah kondisi dimana pasien kendati penyakit yang dideritanya dapat tetap merasa nyaman secara fisik, psikologis, sosial maupun spiritual serta secara optimal memanfaatkan hidupnya untuk kebahagian dirinya maupun orang lain. Kualitas hidup tidak terkait dengan lamanya seseorang akan hidup karena bukan domain manusia untuk menentukannya. Untuk dapat mencapai kualitas hidup perlu perubahan secara fundamental atas cara pandang pasien terhadap penyakit gagal ginjal terminal (GGT) itu sendiri.

Hasil analisis data Zurmeli (2012) dari variabel kualitas hidup responden menunjukkan lebih dari separuh responden memiliki kualitas hidup kurang baik sebanyak 54 orang $(51,4 \%)$.

Kualitas hidup pasien CKD yang menjalani terapi hemodialisis masih merupakan masalah yang menarik perhatian para profesional kesehatan. Kualitas hidup pasien yang optimal menjadi isu penting yang harus diperhatikan dalam memberikan pelayanan keperawatan yang komprehensif.

Menurut Supriyadi (2011) bahwa kualitas hidup pasien GGK sebagian besar berada pada tingkat sedang sebelum dilakukan hemodialisa sebanyak 16 responden $(53,3 \%)$ dan setelah dilakukan hemodialisa seluruh responden berada pada tingkat kualitas hidup sedang (100\%). Walaupun semua pada tingkat kualitas hidup sedang, akan tetapi dari masing-masing responden berbeda nilainya. Ini mungkin juga tergantung dari persepsi responden dan tingkat keparahan penyakitnya, juga karena GGK tidak bisa disembuhkan. Hal ini sesuai dengan pernyataan Suhud (2005) bahwa pasien GGK akan mempunyai ketergantungan akan terapi hemodialisa.

\section{Analisis Bivariat}

\section{Hubungan Usia Dengan Kualitas Hidup Pasien CKD yang menjalani Hemodialisa}

Berdasarkan hasil penelitian yang dilakukan bahwa 57 responden dengan umur < 20 dan > 35 tahun terdapat 10,5\% reponden memiliki tingkat kualitas hidup rendah, sebanyak 35,1\% kualitas hidup sedang dan 54,4\% memiliki tingkat kualitas hidup tinggi. Sedangkan dari 30 responden umur 20-35 tahun terdapat 50\% memiliki kualitas 
rendah, sebanyak 20\% memiliki tingkat kualitas sedang dan sebanyak $30 \%$ memiliki kualitas tinggi.

Dari hasil uji statistic chi-square di dapat $x^{2}=9,661$ dengan nilai $p=0,008<$ 0,05 , ini menunjukkan bahwa terdapat hubungan yang bermakna antara usia dengan kualitas hidup pasien CKD yang menjalani hemodialisa di RSUD Dr. M. Yunus Bengkulu tahun 2016.

Budiarto dan Anggraeni (2002) menambahkan bahwa pada hakikatnya suatu penyakit dapat menyerang setiap orang pada semua golongan umur, tetapi ada penyakitpenyakit tertentu yang lebih banyak menyerang golongan umur tertentu. Penyakitpenyakit kronis mempunyai kecenderungan meningkat dengan bertambahnya umur, sedangkan penyakit-penyakit akut tidak mempunyai suatu kecenderungan yang jelas. Walaupun secara umum kematian dapat terjadi pada setiap golongan umur, tetapi dari berbagai catatan diketahui bahwa frekuensi kematian pada golongan umur berbedabeda, yaitu kematian tertinggi pada golongan umur 0-5 tahun dan kematian terendah terletak pada golongan umur 15-25 tahun dan akan meningkat lagi pada umur 40 tahun ke atas. Dari gambaran tersebut dapat dikatakan bahwa secara umum kematian akan meningkat dengan meningkatnya umur. Hal ini disebutkan berbagai faktor, yaitu pengalaman terpapar oleh faktor penyebab penyakit, faktor pekerjaan, kebiasaan hidup atau terjadinya perubahan dalam kekebalan. Penyakit kronis seperti hipertensi, penyakit jantung koroner, dan karsinoma lebih banyak menyerang orang dewasa dan lanjut usia, sedangkan penyakti kelamin, AIDS, kecelakaan lalu lintas, penyalahgunaan obat terlarang banyak terjadi pada golongan umur produktif yaitu remaja dan dewasa. Hubungan antara umur dan penyakti tidak hanya pada frekuensinya saja, tetapi pada tingkat beratnya penyakit, misalnya staphilococcus dan escheria coli akan menjadi lebih berat bila menyerang bayi daripada golongan umur lain karena bayi masih sangat rentan terhadap infeks.

Penelitian ini sejalan Penelitian Depkes (2007 dalam Notoatmodjo, 2012) tentang propil kesehatan Indonesia mengatakan bahwa, perilaku merokok dengan kelompok umur dapat disimpulkan tidak ada hubungannya. Meskipun demikian dapat dikatakan bahwa presentase rendah perilaku tidak merokok adalah pada umur antara 25-59 tahun.

\section{Hubungan Jenis Kelamin Dengan Kualitas Hidup Pasien CKD yang menjalani Hemodialisa}

Berdasarkan hasil penelitian di RSUD Dr. M. Yunus Bengkulu tahun 2016 di ketahui bahwa dari 26 responden dengan jenis kelamin Laki-laki terdapat 26,9\% reponden memiliki tingkat kualitas hidup rendah, sebanyak 53,8\% kualitas hidup sedang dan 19,2\% memiliki tingkat kualitas hidup tinggi. Sedangkan dari 41 responden berjenis kelamin Perempuan terdapat 9,8\% memiliki kualitas rendah, sebanyak 19,5\% memiliki tingkat kualitas sedang dan sebanyak 70,7\% memiliki kualitas tinggi.

Hasil analisis chi-square di dapat $x^{2}=16,88$ dengan nilai $p=0,000<0,05$, ini menunjukkan bahwa terdapat hubungan yang bermakna antara jenis kelamin dengan kualitas hidup pasien CKD yang menjalani hemodialisa di RSUD Dr. M. Yunus Bengkulu tahun 2016.

Penelitian ini sejalan dengan konsep Budiarto, Anggraeni, (2002) yang menyatakan setiap penyakit dapat menyerang manusia baik laki-laki maupun perempuan, tetapi pada beberapa penyakit terdapat perbedaan frekuensi antara laki-laki dan perempuan. Hal ini antara lain disebabkan perbedaan pekerjaan, kebiasaan hidup, genetika atau kondisi fisiologis penelitan Yuliaw (2010) menyatakan bahwa laki-laki 
mempunyai kualitas hidup lebih jelek dibandingkan perempuan dan semakin lama menjalani terapi hemodialisa akan semakin rendah kualitas hidup penderita.

Penelitian Depkes (2007 dalam Notoatmodjo, 2012) tentang propil kesehatan Indonesia mengatakan bahwa, perilaku tidak merokok pada perempuan jelas lebih tinggi dibandingkan dengan laki-laki. (Notoatmodjo, 2012) melakukan survei tentang melakukan aktivitas fisik secara cukup berdasarkan latar belakang atau karakteristik individu. Ternyata kelompok laki-laki lebih banyak beraktivitas fisik secara cukup dibandingkan dengan kelompok perempuan. Berdasarkan hasil penelitian Yuliaw (2010) bahwa responden memiliki karakteristik individu yang baik hal ini bisa dilihat dari jenis kelamin, bahwa perempuan lebih banyak menderita penyakit gagal ginjal kronik, sedangkan laki-laki lebih rendah.

\section{Hubungan Penghasilan dengan Kualitas Hidup Pasien CKD yang Menjalani Hemodialisa}

Berdasarkan hasil penelitan ada hubungan penghasilan dengan kualitas hidup pasien CKD yang menjalani hemodialisa di RSUD Dr. M. Yunus Bengkulu tahun 2016. Hal ini terlihat dari 27 responden dengan berpenghasilan Kurang terdapat 29,6\% reponden memiliki tingkat kualitas hidup rendah, sebanyak 56,6\% kualitas hidup sedang dan 14,8\% memiliki tingkat kualitas hidup tinggi. Sedangkan dari 40 responden berpenghasilan cukup/lebih terdapat 7,5\% memiliki kualitas rendah, sebanyak 17,5\% memiliki tingkat kualitas sedang dan sebanyak $75 \%$ memiliki kualitas tinggi.

Dari hasil uji statistic chi-square di dapat $x^{2}=23,424$ dengan nilai $p=0,000<$ 0,05 , ini menunjukkan bahwa terdapat hubungan yang bermakna antara penghasilan dengan kualitas hidup pasien CKD yang menjalani hemodialisa di RSUD Dr. M. Yunus Bengkulu tahun 2016.

Penghasilan yang rendah akan berhubungan dengan pemanfaatan pelayanan kesehatan maupun pencegahan. Seseorang yang kurang memanfaatkan fasilitas pelayanan kesehatan yang ada mungkin karena tidak mempunyai cukup uang untuk membeli obat atau membayar tranportasi (Notoadmodjo, 2012).

Penelitian ini tidak sejalan dengan penelitian yang dilakukan oleh Butar (2013) hasil penelitian menunjukkan bahwa karakteristik yang tidak memiliki hubungan yang signifikan dengan kualitas hidup adalah usia, jenis kelamin, suku, agama, status perkawinan, pendidikan, dan penghasilan/ekonomi.

\section{Hubungan Depresi Pasien dengan Kualitas Hidup Pasien CKD yang Menjalani Hemodialisa}

Berdasarkan hasil penelitan ada hubungan depresi dengan kualitas hidup pasien CKD yang menjalani hemodialisa di RSUD Dr. M. Yunus Bengkulu. Hal ini terlihat dari 21 responden dengan memiliki tingkat depresi berat terdapat 38,1\% reponden memiliki tingkat kualitas hidup rendah, sebanyak $61,9 \%$ kualitas hidup sedang dan $0 \%$ memiliki tingkat kualitas hidup tinggi. Dari 6 responden memiliki tingkat Depresi sedang terdapat 33,3\% memiliki tingkat kualitas hidup rendah, sebanyak 16,7\% kualitas hidup sedang dan 50\% memiliki tingkat kualitas hidup tinggi. Dari 17 responden memiliki tingkat depresi ringan terdapat 5,9\% memiliki tingkat kualitas hidup rendah, sebanyak $47,1 \%$ kualitas hidup sedang dan $47 \%$ memiliki tingkat kualitas hidup tinggi. Sedangkan dari 23 responden memiliki tingkat depresi normal 100\% memiliki kualitas tinggi. 
Kualitas hidup merupakan kondisi dimana pasien kendati penyakit yang dideritanya dapat tetap merasa nyaman secara fisik, psikologis, sosial maupun spiritual. Depresi berkaitan erat dengan kulitas hidup pasien. Berdasarkan teori kulitas hidup pasien dapat dilihat dari aspek fisik, psikologis, sosial, dan spiritual. Kulitas hidup pasien yang baik dari segi fisik dapat dilihat dari sedikitnya keluhan fisik yang dialami seperti lelah, sesak, kesulitan beraktivitas, pusing, mual, odema, dan lain-lain. Sedangkan untuk masalah sosial dapat dilihat dari dukungan keluarga yang baik, dukungan dari lingkungan, tenaga kesehatan, dan dukungan dari pasangan. Jika keluhan-keluhan fisik, psikologis, dan spiritual ini tidak dialami pasien dan pasien merasa nyaman dengan keadaan maka dapat dikatakan kulitas hidup pasien baik. Sehingga dapat mengurangi tingkat depresi pada pasien, dikarenakan stresor yang diperoleh oleh pasien merupakan stresor yang positif.

Dari hasil uji statistic chi-square di dapat $x^{2}=48,161$ dengan nilai $p=0,000<$ 0,05 , ini menunjukkan bahwa terdapat hubungan yang bermakna antara depresi dengan kualitas hidup pasien CKD yang menjalani hemodialisa di RSUD Dr. M. Yunus Bengkulu tahun 2016.

Berdasarkan supriyadi (2011) Pada dimensi psikologis kualitas hidup pasien GGK sebelum menjalani HD sebagian besar merasa cemas setiap akan dilakukan tindakan dialisis terutama responden yang masih menggunakan akses temporer baik double lumen melalui vena subklavia maupun akses femoralis. Disamping rasa sakit saat insersi juga risiko yang sering ditimbulkan oleh tindakan pemasangan seperti hematome, thrombosis vena subklavia, ataupun infeksi yang akan menimbulkan demam tinggi saat berlangsungnya dialisis. Kegelisahan responden juga tampak saat akan dimulainya prosedur-prosedur tindakan HD dengan banyak bertanya kepada perawat atau akan memilih perawat yang akan melakukan insersi pada responden.

\section{Hubungan Dukungan Keluarga dengan Kualitas Hidup Pasien CKD yang Menjalani Hemodialisa}

Berdasarkan hasil penelitian di RSUD Dr. M. Yunus Bengkulu tahun 2016, diperoleh di ketahui bahwa dari 24 responden dengan memiliki kurang dalam dukungan keluarga terdapat $45,8 \%$ reponden memiliki tingkat kualitas hidup rendah, sebanyak 37,5\% kualitas hidup sedang dan 16,7\% memiliki tingkat kualitas hidup tinggi. Sedangkan dari 43 responden baik dalam dukungan keluarga terdapat 0\% memiliki kualitas rendah, sebanyak 30,2\% memiliki tingkat kualitas sedang dan sebanyak 69,8\% memiliki kulaitas tinggi. Dari hasil uji statistic chi-square di dapat $x^{2}=$ 28,515 dengan nilai $p=0,000<0,05$, ini menunjukkan bahwa terdapat hubungan yang bermakna antara dukungan keluarga dengan kualitas hidup pasien CKD yang menjalani hemodialisa.

Penelitian ini didukung Zurmeli (2012) dengan hasil uji statistik didapatkan nilai pvalue $=0,002<\alpha 0,05$ maka dapat disimpulkan bahwa ada hubungan antara dukungan keluarga dengan kualitas hidup pasien GGK yang menjalani terapi hemodialisis di RSUD Arifin Achmad Pekanbaru.

Faktor-faktor yang mempengaruhi dukungan keluarga lainnya adalah kelas sosial ekonomi orangtua. Kelas sosial ekonomi disini meliputi tingkat pendapatan atau pekerjaan orang tua dan tingkat pendidikan. Dalam keluarga kelas menengah, suatu hubungan yang lebih demokratis dan adil mungkin ada, sementara dalam keluarga kelas bawah, hubungan yang ada lebih otoritas atau otokrasi. Selain itu orang tua dengan 
kelas sosial menengah mempunyai tingkat dukungan, afeksi dan keterlibatan yang lebih tinggi daripada orang tua dengan kelas sosial bawah.

Hal ini sama dengan hasil penelitian yang dilakukan oleh Supriyadi (2011) dimana setelah menjalani HD sebagian besar pasien berada pada tingkat kualitas hidup tinggi. Responden bisa mengungkapkan semua ide ataupun berpendapat tentang segala sesuatu kepada perawat sehingga tercipta kelompok sosial yang diharapkan responden. Peneliti menilai bahwa keadaan tersebut juga tergantung dari dukungan dari keluarga yang besar. Dimana disetiap pasangan selalu mendampingi responden saat pelaksanaan HD. Perawat dan tenaga medis merupakan manifestasi ketergantungan responden pada kelompok sosial yang akan memberikan pertolongan langsung pada saat responden membutuhkan bantuan.

Beberapa artikel juga menyatakan bahwa pasien yang menjalani hemodialisis cenderung mengalami depresi. Depresi sering terjadi karena gangguan fisik dan psikis yang menyebabkan keterbatasan dalam melakukan aktivitas sehari-hari, ketergantungan pada dialisis seumur hidup dan masalah finansial. Pasien yang mengalami depresi juga mempunyai kualitas hidup yang lebih buruk jika dibandingkan dengan pasien yang tidak depresi (Son et al, 2009). Keluhan fisik yang paling sering diungkapkan oleh pasien yang menjalani hemodialisis adalah kelelahan, tidak tahan cuaca dingin, pruritus, kelemahan ekstremitas bawah, dan kesulitan tidur (Yong et al, 2009). Selain itu gangguan yang paling sering dialami pasien adalah disfungsi seksual atau gangguan ereksi pada pasien pria Mailani (2015).

\section{SIMPULAN}

Berdasarkan hasil penelitian tentang faktor-faktor yang mempengaruhi kualitas hidup pasien CKD yang menjalani hemodialisa dapat disimpulkan bahwa :

Hampir seluruh responden memiliki umur $<20$ dan $>35$ tahun. Lebih dari sebagian responden memiliki jenis kelamin Perempuan. Lebih dari sebagian responden $(59,7 \%)$ memiliki penghasilan cukup/lebih. Hampir sebagian dari responden $(34,3 \%)$ memiliki tingkat depresi. Lebih dari sebagian responden $(64,2 \%)$ memiliki baik dalam dukungan keluarga. Lebih dari sebagian responden $(50,7 \%)$ memiliki kualitas hidup tinggi.

Ada hubungan hubungan usia, jenis kelamin, penghasilan,depresi,dan dukungan keluarga dengan kualitas hidup pasien CKD yang menjalani hemodialisa dengan nilai $p$ $=0,008<0,05$.

Ada hubungan antara dukungan keluarga dengan kualitas hidup pasien CKD yang menjalani hemodialisa dengan nilai $p=0,000<0,05$.

\section{SARAN}

Berdasarkan hasil penelitian yang telah dilakukan maka peneliti ingin memberikan saran kepada beberapa pihak yang terkait:

1. Bagi Rumah Sakit

Penelitian ini dapat digunakan sebagai pertimbangan dalam menangani penderita hemodialisa.

2. Bagi Masyarakat

Diharapkan dapat menjadi informasi dan barmanfaat bagi masyarakat khususnya pasien yang menjalani hemodialisa untuk dapat mengerti tentang pentingnya dukungan keluarga dan kualitas hidup pasien CKD yang menjalani terapi hemodialisa. 
3. Bagi Progam Studi Keperawatan

Hasil penelitian ini dapat menjadi masukan bagi perawat untuk memberikan pendidikan kesehatan kepada keluarga pasien tentang pentingnya pemberian dukungan keluarga dalam meningkatkan kualitas hidup pasien CKD yang menjalani terapi hemodialisa.

4. Bagi Peneliti Selanjutnya.

Hasil penelitian ini dapat dijadikan sebagai informasi dan data tambahan dalam penelitian keperawatan dan untuk dikembangkan bagi penelitian selanjutnya dalam ruang lingkup yang sama.

\section{DAFTAR PUSTAKA}

Aguswina. (2012). Karakteristik Pasien dan Kualitas Hidup Pasien Gagal Ginjal Kronik yang Menjalani Terapi Hemodialisa. Jurnal Online. URL: http:// download. portalgaruda. org/ pada tanggal 4 November 2015

Brunner \& Suddarth. (2002). Buku Ajar Keperawatan Medikal Bedah, Ed 8. Jakarta: EGC

Budiarto \& Anggraeni. (2002). Pengantar Epidemiologi. Edisi 2. Jakarta: EGC

Butar, B., Aguswina. (2013). Hubungan Karakteristik Pasien dengan Kualitas Hidup Pasien Gagal Ginjal Kronis yang Menjalani Hemodialisa di Rumah Sakit Umum Pusat Haji Adam Malik Medan

Hay, R. D. (2010). The Medical Outcomes Study (MOS): Meansuring Functioning and Wellbeing. URL : http://www.rang.org_pada tanggal 4 November 2015

Kazama. (2009). The Risk of Gallbladder Stone Formation is Increased in Patients with Predialysis Chronic Kidney Disease but Not, ose Undergoing Chronic Hemodialysis terapy". Nephron Clin Pract,111

Mailani, F. (2015). Kualitas Hidup Pasien Penyakit Ginjal Kronik yang Menjalani Hemodialisis: Systematic Review. Ners Jurnal Keperawatan, 11(1), 1-8. ISSN1907-686X

Marilyn, D. E. (2012). Rencana Asuhan Keperawatan. Ed. 3. Jakarta: EGC

Rochmayanti (2011). Analisis Faktor-Faktor yang Mempengaruhi Kualitas Hidup Pasien Penyakit Jantung Koroner di Rumah Sakit Pelni Jakarta 2011. E- Jurnal, 4 (1) Januari - Juli 2017

Supriyadi. (2011). Tingkat Kualitas Hidup Pasien Gagal Ginjal Kronik Terapi Hemodialisis. Jurnal Kesehatan Masyarakat. KEMAS, 6(2), 107-112 URL : http://journal.unnes.ac.id/index.php/kemas

Suharyanto \& Madjid. (2012). Asuhan Keperawatan pada Klien dengan Gangguan Sistem Perkemihan; Copy Editor: Agung Wijaya, A.md-. Jakarta: TIM

Suhud, M. (2005). Cuci Darah Demi Kualitas Hidup. Kompas Syb

Son, Y., J., Choi, K. Y., Park,Y. R., Bae, J. L. (2009). Depression, Symptoms and the Quality of Life Patients on Hemodialysis for End Stage Renal Disease. American Journal Nephrology,29, 36-42. doi:10.1159/000150599

Yuwono, A. (2010). Kualitas Hidup menurut Spitzer pada Penderita Gagal Ginjal Terminal yang Menjalani Hemodialisa di Unit Hemodialisis RSUP Dr. Kariadi Semarang. Diakses dari http://www.unimus.ac.id/index.pdf. pada tanggal 3 Nopember 2015

Yuliaw, A. (2009). Hubungan Karakteristik Individu dengan Kualitas Hidup Dimensi Fisik Pasien Gagal Ginjal Kronik di RS Dr. Kariadi Semarang. Diakses 
daridigilib.unimus.ac.id/files/disk1/106/jtpunimus-gdl-annyyuliaw-5289-2-bab2. pdf pada tanggal 29 Agustus 2013

Yong, D. S. P., Kwok, A. O. L.,Wong, D. M. L. (2009). Symptom Burden and Quality of Life in End Stage Renal Disease: A Study of Patients on Dialysis and Palliative Care. Palliative medicine Journal, 23,111-119. DOI10.1177/0269216308101099

Zurmeli. (2012). Hubungan Dukungan Keluarga dengan Kualitas Hidup Pasien Gagal Ginjal Kronik yang Menjalani Terapi Hemodialisis di RSUD Arifin Achmad Pekanbaru 